\title{
Image Analysis of Morphometric Evaluation from the Heart Valves for Age Estimation in Thai Population
}

\author{
Análisis de la Evaluación Morfométrica de las Valvas Cardíacas \\ para la Estimación de la Edad en la Población Tailandesa
}

\author{
Treerat Gumpangseth ${ }^{1,2}$; Pornhatai Komutrattananont ${ }^{1,2}$; Patison Palee $^{3}$; \\ Sukon Prasitwattanaseree ${ }^{4} \&$ Pasuk Mahakkanukrauh $^{2,5,6}$
}

\begin{abstract}
GUMPANGSETH, T.; KOMUTRATTANANONT, P.; PALEE, P.; PRASITWATTANASEREE, S. \& MAHAKKANUKRAUH, P. Image analysis of morphometric evaluation from the heart valves for age estimation in Thai population. Int. J. Morphol., 38(3):726730,2020
\end{abstract}

SUMMARY: Determination of age represents one of the most important aspects in forensic identification. Through aging, changes can occur in morphological structures of the heart valves. The objective is to examine the relationship between the dimensions of the rigth atrioventricular (tricuspid), pulmonary, left atrioventricular (mitral), and aortic valves and age at death. Sixty fresh human hearts were obtained from Department of Anatomy and Department of Forensic Medicine, Faculty of medicine, Chiang Mai University, Thailand. The age of individuals was between 20-90 years. We investigated the morphometric parameters of the valves were taken including: valve circumference, length, the height and area of each leaflet. All parameters were measured by using specific image analysis software. The correlation test and predictive equation were established. The positive correlation between the circumference, area of posterior leaflet, height of anterior leaflet, and area of anterior leaflet of the rigth atrioventricular valve were found. The left atrioventricular valve showed correlation with age in circumference, length and area of posterior leaflet. For the pulmonary and aortic valves, there were correlated between circumference at sinotubular junction and leaflet sizes in almost leaflets. The circumference at sinotubular junction of the pulmonary valve was highest significantly correlation with age $(\mathrm{r}=0.693)$. The predictive equation was age $=$ $-3.659+0.652$ (Circumference at sinotubular junction of the pulmonary valve) with standard error of \pm 14.7 years. Additional knowledge of morphometric features in human heart valves and its relationship with age could be used as age indicator in forensic field.

KEY WORDS: Age; Heart valve; Image analysis; Morphometry.

\section{INTRODUCTION}

Personal identification is a critical process for forensic anthropology at the present time. Particularly when finding the deceased person in form of damage, burning or fragmentation, due to possible various events such as bombing, murder, and disasters. Several factors affect and complicate the identification process. Generally, the biological profile of unidentified persons were represented by recovered skeletal remains (Christensen et al., 2014). The biological profile comprises of basis information which are sex, age, ancestry and stature. For primary identification, establishing a biological profile is key information to find unknown deceased individuals, which is useful to narrower identification and reduce the identify duration. Age at death is the one of biological profile which was an important key in forensic identification (Thompson \& Black, 2006). Conventional methods for age estimation are based on the assessment of developmental and degenerative changes in the skeletons. Beside the bones, the intervertebral disc (Ritz \& Schütz, 1993), cartilage (Thadathil et al., 2017), arteries (Powell et al., 1992), and skin (Ritz-Timme et al., 2003) were selected in age estimating study. For the forensic autopsy procedure, the step of thorax exposer was usually carried out and was not complicated, and the heart was dissected and examined (Saukko \& Knight, 2015). Hence, this study focused in the heart valves because age-related changes were found in the valves in the structural components.

\footnotetext{
${ }^{1} \mathrm{PhD}$ Degree Program in Anatomy, Faculty of Medicine, Chiang Mai University, Chiang Mai, 52000, Thailand.

${ }^{2}$ Department of Anatomy, Faculty of Medicine, Chiang Mai University, Chiang Mai 50200, Thailand.

${ }^{3}$ College of Arts Media and Technology, Chiang Mai University, Chiang Mai, 50200, Thailand.

${ }^{4}$ Department of Statistics, Faculty of Science, Chiang Mai University, Chiang Mai, 50200, Thailand.

${ }^{5}$ Forensic Osteology Research Center, Faculty of Medicine, Chiang Mai University, Chiang Mai, 50200, Thailand

${ }^{6}$ Research Cluster in Osteology Research and Training Center (ORTC), Chiang Mai University, Chiang Mai, 50200, Thailand.
} 
Cardiac valves are thin and translucent tissues which attach to the heart wall and have functions to regulate unidirectional blood flow throughout the heart and prevent blood regurgitation (Pham et al., 2017). The rigth atrioventricular (tricuspid) and left atrioventricular (mitral) valves are the atrioventricular valve group that separate the atria and the ventricles. The semilunar valve consists of the pulmonary and aortic valves which separates the ventricles from the pulmonary artery and aorta, respectively. Age is an important factor which has an impact on the microstructural and macrostructural changes of the cardiac valves including cardiac functions (Misfeld \& Sievers, 2007). Previous literature studies describe the gross anatomy of cardiac valves in human and its associated with age by different methods. There was a relationship between the thickness, valve circumferences, luminal area at sinotubular junction, valve diameter, and size of leaflet in height and length and age. According to previous literature, there was no study age estimation using the human heart valves. Recently, image processing technology is more applicable tool in the medical field, such as diagnosis of pathological condition. Image analysis is software tool for differentiating and quantifying the characteristics of the images research. This tool is becoming increasing use because it is conveniently and cost effectively (PratsMontalbán et al., 2011). Thus, investigation into the morphometry of the heart valves in human with age changes are of great importance and its correlation with age may be used as an age indicator. The purposes of this study were to examine the different dimensions of the valves and analyzed the relationship between the morphometry of the valve and age in a Thai population.

\section{MATERIAL AND METHOD}

All of 60 fresh human hearts were derived from cadavers in Department of Forensic Medicine and the Department of Anatomy, Faculty of Medicine, Chiang Mai University, Thailand. The aged was ranged between 20-90 years (mean $=60.18$ years) with known age and sex. Ethical approval was provided by The Research Ethics Committee, Faculty of Medicine, Chiang Mai University. The exclusion criteria were gross severe calcification valve, perforation or rupture of valve leaflet, congenital valve disease such as bicuspid aortic valve, the leaflet become fused like rheumatic valve disease, and damaged valve by endocarditis. We cut the rigth atrioventricular valve region between the anterior and posterior leaflets. The anterior and right leaflets of the pulmonary valve will be cut separately to spread out the valve. For the left atrioventricular valve, we cut the valve between the anterior and posterior leaflets at lateral papillary muscle. Cutting the right and left coronary leaflets separately to spread out the aortic valve. Then, placed on the white background and photographed with a scale using digital camera with tripod. We designed the specific image analysis program for valve measurements in this study. These morphometric parameters were included as follow (Figs. 1-4)

1) Valve circumference: defined as total length along the valve attachment

2) Attachment length of leaflet: defined as the horizontal distance along the length of the valve leaflet

3) Maximum height of leaflet: defined as the maximum vertical distance from the free edge to its attachment site of the leaflet.

4) Circumference at sinotubular junction: total length along the commissural point of the leaflet.

5.) Area of leaflet: defined as valve area of each leaflet.

All parameters were performed by using image analysis program to calculated theses valve dimensions. Statistical analysis was assessed using SPSS 19 software. The relationship between the valve parameters and age were determined using Pearson correlation. Finally, linear regression analysis was used to establish the equation of predicted age.

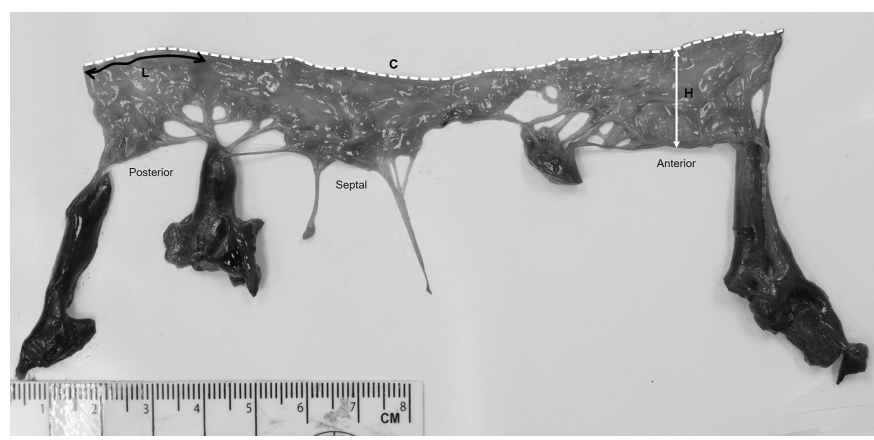

Fig. 1. The morphometric parameters of the rigth atrioventricular valve. Circumference $(\mathrm{C})$; maximum height $(\mathrm{H})$; and length of leaflet $(\mathrm{L})$.

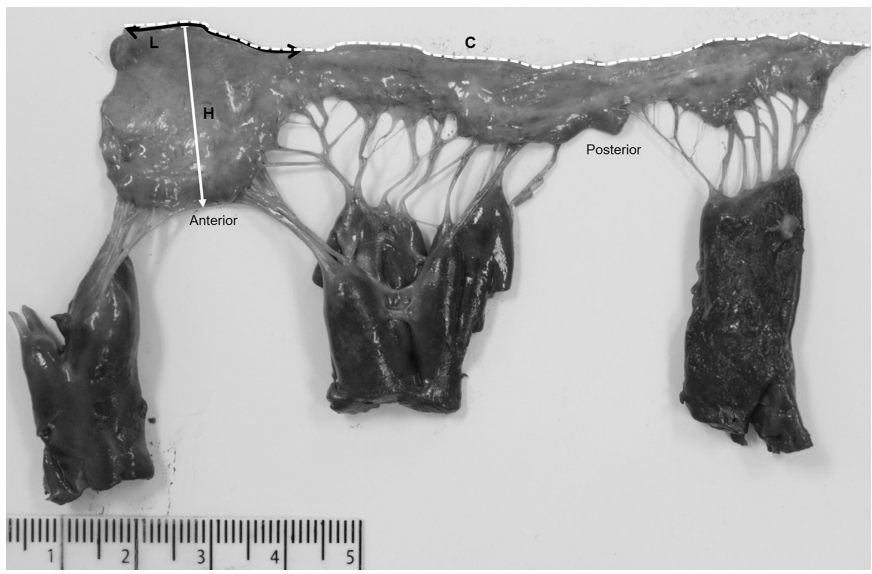

Fig. 2. The morphometric parameters of the left atrioventricular valve. Circumference $(\mathrm{C})$; maximum height $(\mathrm{H})$; and length of leaflet $(\mathrm{L})$. 


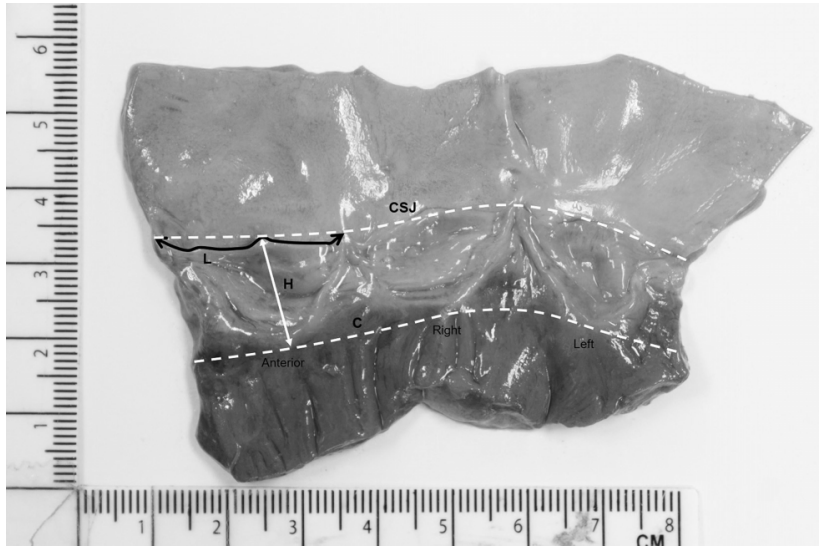

Fig. 3. The morphometric parameters of the pulmonary valve. Circumference at attachment (C); maximum height (H); length (L); circumference at sinotubular junction (CSJ).

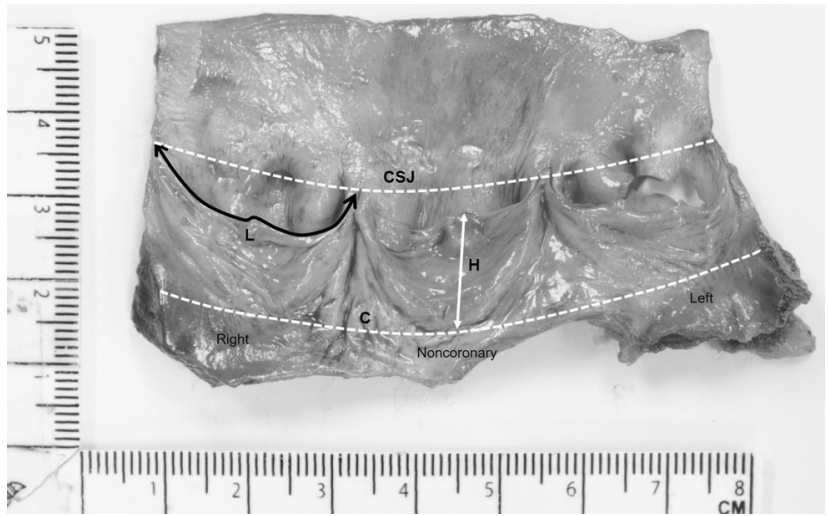

Fig. 4. The morphometric parameters of the aortic valve. Circumference at attachment $(\mathrm{C})$; maximum height $(\mathrm{H})$; and length (L); circumference at sinotubular junction (CSJ).

Table I. Dimension of the rigth atrioventricular valve.

\begin{tabular}{lccc}
\hline & $\begin{array}{c}\text { Mean height } \pm \\
\text { S.D. }(\mathrm{mm})\end{array}$ & $\begin{array}{c}\text { Mean length } \pm \\
\text { S.D. }(\mathrm{mm})\end{array}$ & $\begin{array}{c}\text { Mean area } \pm \text { S.I } \\
\left(\mathrm{mm}^{2}\right)\end{array}$ \\
\hline Posterior lea flet & $22.1 \pm 2.8$ & $47.8 \pm 16.1$ & $494.7 \pm 149.5$ \\
Septal leaflet & $15.2 \pm 2.7$ & $105.2 \pm 23.5$ & $638.9 \pm 149.5$ \\
Anterior leaflet & $19.3 \pm 3.6$ & $41.5 \pm 15.5$ & $371.103 .5 \pm$ \\
\hline
\end{tabular}

Table II. Dimension of the left atrioventricular valve.

\begin{tabular}{lccc}
\hline & $\begin{array}{c}\text { Mean height } \\
\pm \text { S.D. }(\mathrm{mm})\end{array}$ & $\begin{array}{c}\text { Mean length } \pm \\
\text { S.D. }(\mathrm{mm})\end{array}$ & $\begin{array}{c}\text { Mean area } \pm \text { S. } \\
\left(\mathrm{mm}^{2}\right)\end{array}$ \\
\hline Anterior leaflet & $23.2 \pm 3.9$ & $67.6 \pm 28.5$ & $619.9 \pm 109.6$ \\
Posterior leaflet & $15.6 \pm 2.9$ & $115.0 \pm 31.4$ & $654.6 \pm 178.1$ \\
\hline
\end{tabular}

Table III. Dimension of the pulmonary valve.

\begin{tabular}{lccc}
\hline & $\begin{array}{c}\text { Mean length } \\
\pm \text { S.D. }(\mathrm{mm})\end{array}$ & $\begin{array}{c}\text { Mean height } \pm \\
\text { S.D. }(\mathrm{mm})\end{array}$ & $\begin{array}{c}\text { Mean area } \pm \text { S.D. } \\
\left(\mathrm{mm}^{2}\right)\end{array}$ \\
\hline Anterior leaflet & $38.8 \pm 5.7$ & $14.4 \pm 2.3$ & $292.0 \pm 83.2$ \\
Right leaflet & $40.2 \pm 6.4$ & $14.9 \pm 2.2$ & $307.8 \pm 77.1$ \\
Left leaflet & $40.6 \pm 6.0$ & $14.8 \pm 2.3$ & $313.8 \pm 87.7$ \\
\hline
\end{tabular}

\section{RESULTS AND DISCUSSION}

The results showed all rigth atrioventricular leaflets were different size and shape. Mean total circumference of the rigth atrioventricular valve was $188.7 \pm 31.1 \mathrm{~mm}$. The dimensions of the rigth atrioventricular valve found wide range of variations that showed in Table I. Positive correlation was found between the circumference $(\mathrm{r}=0.543)$, area of posterior leaflet $(\mathrm{r}=0.444)$, height $(\mathrm{r}=0.566)$ and area of anterior leaflet $(\mathrm{r}=0.467) \quad(\mathrm{p}<0.01)$. Observation of the left atrioventricular valve showed common two leaflets as anterior and posterior leaflets. The anterior leaflet was triangular or semicircular shape. The anterior leaflet was larger than the posterior leaflet. Nevertheless, the posterior leaflet was larger length in circumference. Mean circumference of the left atrioventricular valve was $173.4 \pm 40.9 \mathrm{~mm}$. The dimensions demonstrated as Table II. We found significantly correlation with age in circumference $(\mathrm{r}=0.455)$, length $(\mathrm{r}=0.393)$ and area of posterior leaflet $(\mathrm{r}=0.336)$ of the left atrioventricular valve $(\mathrm{p}<0.01)$. For the pulmonary valve, we usually found three leaflets (anterior, right, and left) with crown shaped. There was different size among three pulmonary leaflets (Table III). The mean circumference at attachment site of the pulmonary valve was $106.5 \pm 18.2 \mathrm{~mm}$. The mean circumference at sinotubular junction was $101.8 \pm 21.4 \mathrm{~mm}$. There were significantly correlation between age and circumference at sinotubular junction ( $\mathrm{r}=0.693)$, height $(\mathrm{r}=0.557)$, length $(\mathrm{r}=0.427)$, and area of anterior leaflet $(\mathrm{r}=0.60)$, height $(\mathrm{r}=0.573)$, length $(\mathrm{r}=0.381)$, and area of left leaflet $(\mathrm{r}=0.523)$, height $(\mathrm{r}=0.56)$ and area of right leaflet $(\mathrm{r}=0.542)(\mathrm{p}<0.01)$. We found the aortic valve was thicker than the pulmonary valve and all 3 aortic leaflets were different sizes within the same individual. The circumference at attachment site of the aortic valve was $95.6 \pm 15.2 \mathrm{~mm}$. The circumference at sinotubular junction was $100.4 \pm 19.2 \mathrm{~mm}$. The dimensions of the aortic valve demonstrated as Table IV. There was significant correlation between the circumference at sinotubular junction $(r=0.613)$, height $(r=0.407)$, area of noncoronary leaflet $(\mathrm{r}=0.383)$, length $(\mathrm{r}=0.405)$, height $(\mathrm{r}=0.532)$, and area of right leaflet $(r=0.493)$, length $(r=0.496)$, height $(r=0.584)$, and area of left leaflet $(\mathrm{r}=0.605)$. The predictive equation was established using some parameters of all valve types demonstrated as Table V. From previous literatures, there was no study age estimation from the human heart valves for application in forensic anthropological contexts. However, there were studies age related changes in morphology of the valves using different instruments for measurement the valve dimensions. Reported study by Kitzman et al. 
Table IV. Dimension of the aortic valve.

\begin{tabular}{lccc}
\hline & $\begin{array}{c}\text { Mean length } \\
\pm \text { S.D. }(\mathrm{mm})\end{array}$ & $\begin{array}{c}\text { Mean height } \pm \\
\text { S.D. }(\mathrm{mm})\end{array}$ & $\begin{array}{c}\text { Mean area } \pm \\
\text { S.D. }\left(\mathrm{mm}^{2}\right)\end{array}$ \\
\hline Noncoronary & $37.5 \pm 6.2$ & $14.2 \pm 2.1$ & $271.4 \pm 61.6$ \\
Right leaflet & $36.5 \pm 4.9$ & $13.4 \pm 2.0$ & $261.0 \pm 63.2$ \\
Left leaflet & $35.1 \pm 4.4$ & $13.8 \pm 1.9$ & $249.7 \pm 52.8$ \\
\hline
\end{tabular}

smallest. The mean circumference at sinotubular junction was slightly less than the circumference at annular attachment. In our study, the circumference at sinotubular junction, height, length and area of anterior leaflet, height, length and area of left leaflet, height and area of right leaflet were significantly correlated with age ( $r=0.381-0.693)$. The results were (1988) who investigated the valve circumferences in human hearts in 20-99 years and they found that the average circumference of the rigth atrioventricular valve was increased between 30-70 years in women but were constant in men. Skwarek et al. (2008) found the attachment length of the anterior leaflet of the rigth atrioventricular valve increased significantly between aged 18-40 years and 41-64 years in women. There was no significant difference in men. And the attachment length of the posterior leaflet increased in 41-64 years group. In present study, the valve circumference, area of posterior leaflet, height and area of anterior leaflet were increased progressively with age in the rigth atrioventricular valve. Among all valve types, rigth atrioventricular valve was a complex structure and had most variation in valve geometry. The rigth atrioventricular valve circumference and height of anterior leaflet were used to create the equation for age estimation in which the standard error was 15.8 and 16.4, respectively. The circumference of the left atrioventricular valves was more variations and greatest among other literatures (Roy \& Saha, 2016). The area of left atrioventricular leaflets was similar to the study of Gupta et al. (2012). Moreover, the previous studies described that there were correlation between the valve sizes and height (Eckner et al., 1969), and weight (de Andrade et al., 2005) of the individuals.

The predictive equation established from the left atrioventricular valve using the circumference with standard error of 16.4 years. For the pulmonary valve, there were found similar shape of the valve leaflet and had different sizes. The length and height of three leaflets were similar. The area of left pulmonary leaflet was greatest and anterior leaflet was consistent with the study of van Geemen et al. (2016) and Kitzman et al. that found the leaflet size of the pulmonary valve increased progressively with age and found the average valve circumferences were increased with increasing age in adult life in male and female. We established predictive equation of the pulmonary valves using the valve circumference with a standard error of 14.7 years. The aortic valve had similar morphology to the pulmonary valve, but leaflets had thicker. The mean circumference at sinotubular junction was greater than the circumference at annular attachment. The non-coronary leaflet was greatest in height, length, and area. The left leaflet was lowest in length and leaflet area. van Geemen et al. found that the valve diameter increased with age in the pulmonary and aortic valves. The aortic valve circumference was slightly smaller than the pulmonary valve. Moreover, the size of leaflets in circumferential and radial directions was significantly correlated with age in both valves. These results are consistent with our study. We created the equation from the valve circumference at sinotubular junction and area of left leaflet of the aortic valve with standard error of 16.5 and 17.6 years, respectively. The difference of the valves dimensions was depending on the heart weight, BMI, and race (Rohilla et al., 2015). Our finding results demonstrated that the circumference of all valve types was significantly correlated with increasing age. The correlation of the pulmonary and aortic valves was higher than the rigth atrioventricular and left atrioventricular valves. The circumference at sinotubular junction of the pulmonary valve was highest correlation and least of standard error of equation, followed by the circumference at sinotubular junction of the aortic valve. This study suggested that the human heart valve

Table V. Age prediction equation of the heart valves.

\begin{tabular}{|c|c|c|c|c|}
\hline Parameters & Prediction equation & $\mathrm{R}$ & $\mathrm{R}^{2}$ & $\begin{array}{l}\text { Standard Error } \\
\text { of the Estimate }\end{array}$ \\
\hline \multicolumn{5}{|l|}{ Rigth atrioventricular valve: } \\
\hline - Circumference (C) & Age $=2.864+0.319(\mathrm{C})$ & 0.543 & 0.294 & 15.8 \\
\hline - Height of anterior leaflet (HA) & Age $=2.477+3.075(\mathrm{HA})$ & 0.566 & 0.321 & 16.4 \\
\hline \multicolumn{5}{|l|}{ Left atrioventricular valve: } \\
\hline - Circumference $(\mathrm{C})$ & Age $=24.146+0.202(C)$ & 0.455 & 0.207 & 16.4 \\
\hline \multicolumn{5}{|l|}{ Pulmonary valve } \\
\hline - Circumference at sinotubular (C) & Age $=-3.659+0.652(C)$ & 0.693 & 0.481 & 14.7 \\
\hline - Area of anterior leaflet (AA) & $\mathrm{Age}=20.206+0.141(\mathrm{AA})$ & 0.600 & 0.359 & 15.8 \\
\hline \multicolumn{5}{|l|}{ A ortic valve } \\
\hline -Circumference at sinotubular (C) & Age $=-2.404+0.658(C)$ & 0.613 & 0.376 & 16.48 \\
\hline - Area of left leaflet (AL) & A ge $=-2.377+0.249(\mathrm{AL})$ & 0.605 & 0.366 & 17.58 \\
\hline
\end{tabular}


could be used as age indicator for age estimation if the heart is available, particularly in the aortic and the pulmonary valves. Since these valves had less variations and easy for observation. Future studies should increase the number of young age specimens ( $<40$ years) and sex separately. The current study present age estimation from the human heart valves using specific image analysis software. With aging, the valve morphology can be changes in macrostructures and microstructures. For the gross morphology, the leaflet size, the valve circumference showed significant correlation with increasing age particularly in, the pulmonary and aortic valves. The investigation presented in this study could be used as one of age prediction in forensic identification.

ACKNOWLEDGEMEMTS. This study was funded by Faculty of Medicine, Chiang Mai University, Chiang Mai, Thailand and partially supported by research cluster in Osteology Research and Training Center (ORTC), Chiang Mai University

GUMPANGSETH, T.; KOMUTRATTANANONT, P.; PALEe, P.; PRASITWATTANASEREE, S. \& MAHAKKANUKRAUH, P. Análisis de la evaluación morfométrica de las valvas cardíacas para la estimación de la edad en la población tailandesa. Int. J. Morphol., 38(3):726730, 2020.

RESUMEN: La determinación de la edad representa uno de los aspectos más importantes en la identificación forense. Pueden ocurrir cambios a través del envejecimiento, en las estructuras morfológicas de las válvulas cardíacas. El objetivo de este estudio fue examinar la relación entre las dimensiones de las valvas atrioventricular derecha (tricúspide), pulmonar, atrioventricular izquierda (mitral) y aórtica, y la edad en relación a la muerte. Se obtuvieron sesenta corazones humanos frescos del Departamento de Anatomía y el Departamento de Medicina Forense de la Facultad de Medicina de la Universidad de Chiang Mai, Tailandia. La edad de las personas fluctuaba entre los 20 y 90 años. Investigamos los parámetros morfométricos de las valvas analizadas, incluyendo: circunferencia de la valva, longitud, altura y área de cada valva. Todos los parámetros se midieron utilizando un software de análisis de imagen específico. Se estableció la prueba de correlación y la ecuación predictiva. Se encontró la correlación positiva entre la circunferencia, el área de la valvula posterior, la altura de la valvula anterior y el área de la valvula anterior de la valva atrioventricular derecha. La valva atrioventricular izquierda mostró correlación con la edad en la circunferencia, longitud y área de la valvula posterior. Para las valvas pulmonar y aórtica, se correlacionó entre la circunferencia en la unión sinotubular y el tamaño de las válvulas. La circunferencia en la unión sinotubular de la valva pulmonar fue la mayor correlación significativa con la edad $(\mathrm{r}=$ 0,693 ). La ecuación predictiva fue edad $=-3,659+0,652$ (circunferencia en la unión sinotubular de la valva pulmonar) con error estándar de \pm 14,7 años. El conocimiento adicional de las características morfométricas en las valvas cardíacas humanas y su relación con la edad podría usarse como indicador de edad en el campo forense.

PALABRAS CLAVE: Edad; Valva cardiaca; Análisis de imagen; Morfometría.

\section{REFERENCES}

Christensen, A. M.; Passalacqua, N. V. \& Bartelink, E. J. Forensic Anthropology: Current Methods and Practice. Amsterdam, Academic Press, 2014.

de Andrade, N. M. M.; Tinois, E.; Vieira, R. W.; Braile, D. M.; Petrucci Junior, O.; de Oliveira, P. P. M. \& da Mota Silveira Filho, L. Coefficients of proportions of the atrioventricular valves: an anatomical study of valvar segments of normal individuals. Braz. J. Cardiovasc. Surg., 20(3):255-60, 2005.

Eckner, F. A.; Brown, B. W.; Overll, E. \& Glagov, S. Alteration of the gross dimensions of the heart and its structures by formalin fixation. A quantitative study. Virchows Arch. A Pathol. Pathol. Anat., 346(4):318-29, 1969.

Gupta, C.; Shetti, V. R. \& Manju, B. V. M. Dimensions of the human adult mitral valve in the embalmed cadaver. J. Morphol. Sci., 30(1):6-10, 2012.

Kitzman, D. W.; Scholz, D. G.; Hagen, P. T.; Ilstrup, D. M. \& Edwards, W. D. Age-related changes in normal human hearts during the first 10 decades of life. Part II (maturity): A quantitative anatomic study of 765 specimens from subjects 20 to 99 years old. Mayo Clin. Proc., 63(2):137-46, 1988.

Misfeld, M. \& Sievers, H. H. Heart valve macro- and microstructure. Philos. Trans. R. Soc. Lond. B Biol. Sci., 362(1484):1421-36, 2007.

Pham, T.; Sulejmani, F.; Shin, E.; Wang, D. \& Sun, W. Quantification and comparison of the mechanical properties of four human cardiac valves. Acta. Biomater, 54:345-55, 2017.

Powell, J. T.; Vine, N. \& Crossman, M. On the accumulation of d-aspartate in elastin and other proteins of the ageing aorta. Atherosclerosis, 97(2-3):2018, 1992.

Prats-Montalbán, J. M.; de Juan, A. \& Ferrer, A. Multivariate image analysis: A review with applications. Chemom. Intell. Lab. Syst., 107(1):1-23, 2011.

Ritz-Timme, S.; Laumeier, I. \& Collins, M. J. Aspartic acid racemization: evidence for marked longevity of elastin in human skin. Br. J. Dermatol., 149(5):951-9, 2003.

Ritz, S. \& Schütz, H. W. Aspartic acid racemization in intervertebral discs as an aid to postmortem estimation of age at death. J. Forensic Sci., 38(3):63340, 1993.

Rohilla, A.; Singh, K.; Rohilla, J. \& Chhabra, S. Tricuspid valve morphometry: a new learning from cadavers. Anat. Physiol. Curr. Res., 5(4):185, 2015.

Roy, S. \& Saha, A. Mitral valve beyond classical view - A morphometric evaluation. J. Anat. Soc. India., 65(1):20-3, 2016.

Saukko, P. \& Knight, B. Knight's Forensic Pathology. $4^{\text {th }}$ ed. New York, CRC Press, 2015.

Skwarek, M.; Hreczecha, J.; Dudziak, M.; Jerzemowski, J.; Szpinda, M. \& Grzybiak, M. Morphometric features of the right atrioventricular orifice in adult human hearts. Folia Morphol. (Warsz.), 67(1):53-7, 2008.

Thadathil, R. P. \& Ponnappan, P. Estimation of age from ossification changes in thyroid cartilage of North Kerala population. J. Evid. Based Med. Healthc., 4(70):4158-63, 2017.

Thompson, T. \& Black, S. Forensic Human Identification: An Introduction. New York, CRC Press, 2006.

van Geemen, D.; Soares, A. L. F.; Oomen, P. J. A.; Driessen-Mol, A.; Janssenvan den Broek, M. W. J. T.; van den Bogaerdt, A. J.; Bogers, A. J. J. C.; Goumans, M. J. T. H.; Baaijens, F. P. T. \& Bouten, C. V. C. Age-dependent changes in geometry, tissue composition and mechanical properties of fetal to adult cryopreserved human heart valves. PLoS One, 11(2):e0149020, 2016.

\section{Corresponding author:}

Pasuk Mahakkanukrauh

Department of Anatomy

Faculty of Medicine \& Research Cluster in Osteology

Research and Training Center (ORTC)

Chiang Mai University

Chiang Mai - 50200

THAILAND

Received: 09-10-2019

Accepted: 06-01-2020 